\title{
PENYUSUNAN BASIS DATA SPASIAL SUMBERDAYA AIR MELALUI PARTISIPASI MASYARAKAT \\ (Studi Kasus di Desa Kepuharjo Kecamatan Cangkringan \\ Kabupaten Sleman Provinsi Daerah Istimewa Yogyakarta)
}

\author{
Prima Widayani ${ }^{1}$; Tim KKN-PPM UGM ${ }^{2)}$ \\ 1)Prodi Kartografi Penginderaan Jauh, Jurusan Sains Informasi Geografi dan \\ Pengembangan Wilayah, Fakultas Geografi UGM, primawidayani@ugm.ac.id \\ 2)TIM KKN-PPM UGM Unit 2 Kecamatan Cangkringan
}

\begin{abstract}
The preparation of spatial database of water resources in the village of Kepuharjo Cangkringan Sleman District implemented through local community empowerment. The objective is to assess the potential and utilization of existing surface water resources in the village of Kepuharjo, District Cangkringan based database of water resource potential. Based on results of the discussion, data collection, field survey and data analysis conducted jointly with local communities showed that rain water and stream water that flowed through the pipe from the spring Bebeng and Kalikuning become the main surface water source Kepuharjo Village residents. Surface water potential is very high especially in the rainy season and has not been used optimally and in August and September the village of Kepuharjo experiencing critical water.
\end{abstract}

Keywords : database, water resources, community empowerment.

\section{PENDAHULUAN}

\section{Latar Belakang}

Air merupakan salah satu sumber daya alam yang sangat penting bagi kehidupan manusia. Beragam keperluan membutuhkan sumber daya air seperti untuk keperluan domestik rumah tangga, pertanian, industri, perdagangan dan hampir di setiap sektor usaha memerlukan sumber daya air. Seiring dengan laju pembangunan dan bertambahnya jumlah penduduk, keperluan akan air semakin meningkat. Penggunaan air secara terus menerus jika tidak diimbangi dengan upaya konservasi dan managemen pengelolaan sumber daya air secara benar akan berdampak pada menipisnya cadangan air dan yang paling parah adalah hilangnya sumber untuk supplay atau pasokkan air.

Kesadaran akan pentingnya sumber daya air berawal dari kesadaran pribadi, masyarakat dan berlanjut pada kesadaran nasional dalam upaya melestarikan sumber daya air dan mengelola pemakaian air secara optimal. Masyarakat diajak untuk ikut menjaga dan mengelola sumber daya air yang ada di lingkungan setempat. Peran masyarakat dari yang paling sederhana seperti penghematan penggunaan air, tidak membuang sampai di sungai sampai pada upaya pelestararian atau konservasi daerah tangkapan air hujan dan tempat 
penampungan air (reservoir). Untuk mengetahui banyaknya sumberdaya air yang ada di daerah setempat, masyarakat diajak untuk melakukan pendataan sumber air dan berapa besarnya penggunaan air untuk berbagai keperluan di daerah setempat. Hal ini dilakukan guna memberi kesadaran pada masyarakat terhadap ketersediaan sumber daya air di daerahnya.

Sebagai wujud kongkret dari upaya penyelamatan sumber daya air adalah dengan melakukan pendataan yang nantinya dapat digunakan untuk pembuatan basis data dan pemetaan sumber daya air. Dengan dibuatnya basis data dan pemetaan diharapkan masyarakat dapat mengetahui berapa banyak sumber daya air yang mereka miliki, berapa yang digunakan dan berada dimana saja potensi dan pemanfaatan sumber daya air yang ada di lingkungan mereka. Pembuatan basis data sumber daya air ini dengan mengikutsertakan masyarakat setempat atau yang sering disebut dengan pemberdayaan masyarakat. Pemberdayaan Masyarakat merupakan suatu pendekatan pembangunan yang meliputi perencanaan, pelaksanaan, monitoring, dan pengevaluasian berbagai aktivitas program atau proyek kemasyarakatan yang melibatkan berbagai aktor, seperti pekerja sosial, penyuluh pertanian, guru, dokter, warga setempat, lembaga donor, serta instansi terkait yang saling bekerja sama untuk mendayagunakan sumber-sumber internal dan eksternal bagi perbaikan kualitas hidup masyarakat setempat (local community)(Plan Indonesia 2010).

Saat ini partisipasi masyarakat juga telah berkembang di bidang pemetaan yang sering dikenal dengan Pemetaan Partisiptif (Participatory Mapping). Pemetaan Partisiptif telah menjadi alat kekuatan baru bagi masyarakat untuk menyelamatkan lingkungan. Peta sebagai salah satu bentuk budaya tulisan ternyata mampu memberi gambaran secara keruangan tentang lingkungan, sumber daya, sosial, ekonomi dan budaya. Masyarakat diajak untuk duduk bersama berdiskusi dan menggambarkan lokasi-lokasi sumber air, mendiskusikan besarnya pemanfaatan sampai terjun ke lapangan untuk pengambilan data sesuai dengan kemampuan mereka sebagai masyarakat lokal.

\section{Tujuan}

Tujuan penelitian adalah: 1) membuat basis data spasial sumber daya air permukaan dalam bentuk peta dengan melibatkan masyarakat (participatory mapping) di Desa Kepuharjo, Kecamatan Cangkringan; dan 2) mengkaji potensi dan pemanfaatan sumber daya air permukaan yang ada di Desa Kepuharjo, Kecamatan Cangkringan berdasarkan basis data potensi sumber daya air.

\section{Lingkup Wilayah Kajian}

Lingkup wilayah kajian meliputi seluruh Desa Kepuharjo, Kecamatan Cangkringan, Kabupaten Sleman yang terletak pada koordinat 07'40'42.7"LS 07² $3^{\prime} 00.9^{\prime \prime}$ LS dan 110'27'59.9"BT - 110'28'51.4"BT. Desa Kepuharjo dibatasi oleh Taman Nasional Gunung Merapi di sebelah utara, Desa Wukirsari di sebelah selatan, Desa Umbulharjo di sebelah barat dan Desa Glagaharjo di sebelah 
timur. Luas wilayah Desa kepuharjo sebesar 782,25 hektar yang terbagi dalam 8 dusun yaitu: Dusun Kaliadem, Dusun Jambu, Dusun Petung, Dusun Kopeng, Dusun Batur, Dusun Pagerjurang, Dusun Kepuh dan Dusun Manggong. Jumlah penduduk di Desa Kepuharjo, berdasarkan pada data monografi desa tahun 2008 dan pendataan pada tahun 2010, mencapai 2992 jiwa.

Desa Kepuharjo berada di bagian lereng selatan Gunungapi Merapi sehingga memiliki kondisi topografi yang relatif curam dengan kemiringan lereng hingga lebih dari $60^{\circ}$ pada elevasi antara 540 - 1200 meter di atas permukaan air laut (m dpal). Di sekitar wilayah Desa Kepuharjo terdapat dua sumber mataair besar yaitu mataair Bebeng di Dusun Kopeng dan mataair Umbulwadon di Desa Umbulharjo. Penggunaan lahan di Desa Kepuharjo meliputi permukiman, pertanian, tempat rekreasi, perkantoran, perdagangan, tanah wakaf.

Curah hujan tahunan di Desa Kepuharjo tergolong relatif tinggi antara $\pm 2560 \mathrm{~mm} /$ tahun. Hari hujan di Desa Kepuharjo mencapai \pm 118 hari per tahunnya dengan rerata temperatur hariannya berkisar antara $18-26^{\circ} \mathrm{C}$. Menurut pengolongan tipe iklim Köppen yang didasarkan pada temperatur dan curah hujan maka wilayah Sleman bagian utara tergolong iklim tropis dengan musim hujan berlangsung antara bulan Oktober - April dan musim kemarau berlangsung pada bulan April - Oktober. Musim hujan dipengaruhi oleh angin musim baratlaut yang bersifat basah sedangkan musim kemarau dipengaruhi oleh angin musim bersifat kering.

\section{METODE PENELITIAN}

Proses pembuatan peta dan basis data spasial melalui beberapa tahap yaitu: Tahap Persiapan, Pencarian Data, Pengolahan dan Analisis Data.

\section{Tahap persiapan}

Pada tahap dilakukan sosialisai mengenai program pembuatan basis data dan peta sumberdaya air kepada masyarakat setempat. Tujuannya agar masyarakat mengetahui kegiatan yang akan dilaksanakan dan arti penting melakukan pendataan dan pembuatan basis data spasial sumberdaya air. Pada tahap ini juga dilakukan pembentukan kelompok masyarakat yang bertugas untuk mengumpulkan data sumber daya air yang dipandu oleh mahasiswa dan dosen pembimbing.

\section{Tahap Pencarian Data}

Pada tahap ini peran masyarakat sangat tinggi, masyarakat diajak untuk berdiskusi, duduk bersama untuk mengetahui potensi dan penggunaan sumber daya air yang ada di masyarakat. Setiap kelompok yang mewakili sebuah dusun bertugas menentukan dimana posisi sumber air dan melakukan pendataan penggunan air baik untuk kebutuhan domestik, pertanian, peternakan maupun kebutuhan lainnya. 


\section{Tahap Pengolahan dan Analisis data}

Tahap ini terdiri dari kegiatan : 1) analisis potensi sumberdaya air hujan dan air permukaan; dan 2) analisis kebutuhan air untuk domestik, pertanian, industri, puskesmas, dan prioritas kebutuhan.

\section{Ketersediaan Air}

1) Potensi Air Hujan

Potensi air hujan diperhitungkan berdasarkan besarnya curah hujan yang diperoleh dari stasiun hujan di daerah penelitian dan sekitarnya. Formula untuk menghitung hujan wilayahnya adalah sebagai berikut :

$$
R=\frac{A 1 R 1+A 2 R 2+\cdots A n R n}{A 1+A 2+\cdots A n}
$$

Keterangan:

$\mathrm{R} \quad=$ curah hujan daerah $\left(\mathrm{m}^{3} /\right.$ th)

$\mathrm{A}_{1} \mathrm{~A}_{2} \quad=$ luas bagian antar dua garis isohiet

$R_{1} R_{2}=$ curah hujan rata-rata pada bagian $A_{1}$

2) Potensi Air Permukaan

Pengukuran debit air permukaan dilakukan pada semua mataair dan bak air yang menjadi sumber kebutuhan penduduk di Desa Kepuharjo. Pengukuran debit mataair dilakukan dengan bantuan gelas ukur, ember dan stopwatch. Gelas ukur diletakkan di bawah kucuran air dalam rentang waktu tertentu. Maka, didapatkan volume air tertentu dalam rentang waktu yang tertentu pula. Di satu lokasi, pengukuran dilakukan beberapa kali untuk kemudian direratakan sehingga diperoleh suatu debit yang dapat dianggap mewakili. Data debit yang dihasilkan kemudian dikonversikan pada satuan $\mathrm{m}^{3} /$ detik.

\section{Kebutuhan Air}

1) Kebutuhan Domestik

Kebutuhan air domestik adalah besarnya air yang dibutuhkan untuk memenuhi kebutuhan rumah tangga sehari-hari. Kebutuhan air domestik dipengaruhi oleh jumlah penduduk, tingkat sosial ekonomi, lapangan pekerjaan dan ketersediaan air dimana penduduk bertempat tinggal. Kebutuhan domestik suatu wilayah diperoleh dari kebutuhan orang dalam satu hari dikalikan dengan jumlah penduduk dalam wilayah tersebut. Rumusnya adalah sebagai berikut:

$$
K d m=d \times E P
$$

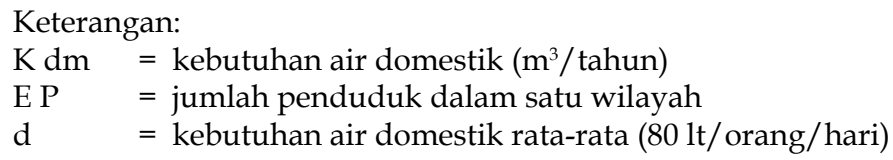




\section{2) Kebutuhan Non Domestik}

Tabel 1.

Kebutuhan Air Setiap Jenis Ternak di Desa Kepuharjo

\begin{tabular}{clc}
\hline No & \multicolumn{1}{c}{ Jenis ternak } & Kebutuhan air (liter/ekor/hari) \\
\hline 1 & Sapi potong & 40 \\
\hline 2 & Sapi perah & 75 \\
\hline 3 & Kambing/domba & 2.5 \\
\hline 4 & Ayam buras & 0.1 \\
\hline 5 & Ayam potong/petelur & 0.25 \\
\hline 6 & Itik & 0.25 \\
\hline 7 & Burung merpati & 0.1 \\
\hline 8 & Kelinci & 0.1 \\
\hline
\end{tabular}

Sumber: Laporan Akhir KPSDA Kabupaten Sleman

\section{Kekritisan Air}

Dengan mengetahui ketersediaan dan kebutuhan air, dapat dilakukan evaluasi mengenai cadangan air yang tersedia di suatu wilayah, yang dapat dinyatakan dengan indeks kekeringan air. Indeks kekeringan air tersebut merupakan perbandingan antara ketersediaan dengan kebutuhan air:

$$
\text { Indeks Kekritisan }=\frac{\text { Kebutuhanair }}{\text { Ketersediaanair }} \text {. }
$$

Klasifikasi indeks kekeringan air menurut Direktorat Bina Program Pengairan adalah sebagai berikut:

Tabel 2.

Kelas Kekritisan Air

\begin{tabular}{ccl}
\hline No & Indeks Kekritisan (\%) & \multicolumn{1}{c}{ Kelas Kekritisan } \\
\hline 1 & $<50$ & Belum Kritis \\
\hline 2 & $50-75$ & Mendekati Kritis \\
\hline 3 & $75-100$ & Kritis \\
\hline 4 & $>100$ & Sangat Kritis \\
\hline Sumber: Bina Program Pengairan, 2005 & \\
\hline
\end{tabular}




\section{HASIL DAN PEMBAHASAN}

\section{Pembuatan basis data dan peta dengan partisipasi masyarakat}

Secara garis besar pemberdayaan masyarakat melalui: 1) pengembangan masyarakat, yaitu mengembangkan potensi, kemampuan dan sikap hidupnya; dan 2) pengorganisasian masyarakat, yaitu mengajak masyarakat untuk mengidentifikasi kebutuhannya, memprioritaskan, dan mencari pemecahannya. Pada pengorganisasian masyarakat, kuncinya adalah menempatkan masyarakat sebagai pelakunya. Untuk itu masyarakat perlu diajak mulai dari perencanaan kegiatan, pelaksanaan, sampai pemeliharaan dan pelestarian. Pelibatan masyarakat sejak awal kegiatan memungkinkan masyarakat memiliki kesempatan belajar lebih banyak. Pada awal-awal kegiatan mungkin pendamping sebagai pendamping akan lebih banyak memberikan informasi atau penjelasan bahkan memberikan contoh langsung. Pada tahap ini masyarakat lebih banyak belajar namun pada tahap-tahap berikutnya pendamping harus mulai memberikan kesempatan kepada masyarakat untuk mencoba melakukan sendiri hingga mampu atau bisa. Jika hal ini terjadi maka dikemudian hari pada saat pendamping meninggalkan masyarakat tersebut, masyarakat sudah mampu untuk melakukannya sendiri atau mandiri.

Pada pembuatan basisdata sumberdaya air di Desa Kepuharjo ini, pemberdayaan masyarakat yang dilakukan masih dalam tahap awal yaitu masyarakat diberikan informasi yang cukup mengenai pentingnya menjaga, memelihara dan mengetahui potensi dan pemanfaatan sumber daya air melalui penyuluhan oleh pendamping. Keterlibatan masyarakat secara langsung lebih banyak dilakukan pada saat perencanaan kegiatan, pengumpulan data dan survai lapangan, sedangkan pada pengolahan dan analisa data lebih banyak dilakukan oleh pendamping. Namun demikian masyarakat tetap diberikan penjelasan sederhana mengenai bagaimana mengolah data dan melihat berapa besarnya potensi sumber daya air yang ada dan berapa besar penggunaannya. Dengan demikian dapat diketahui apakan desa Kepuharjo mengalami kekritisan sumber daya air atau tidak.

\section{Potensi Air Permukaan}

\section{1) Air Hujan}

Air hujan merupakan salah satu sumber air di bumi yang memerankan peranan penting dalam siklus hidrologi. Ada satu stasiun hujan di dekat Desa Kepuharjo yang dapat mewakili kondisi iklim di Desa Kepuharjo. Berdasarkan stasiun hujan tersebut, maka diperoleh data rerata hujan tiap bulannya dari tahun 1998- 2000 


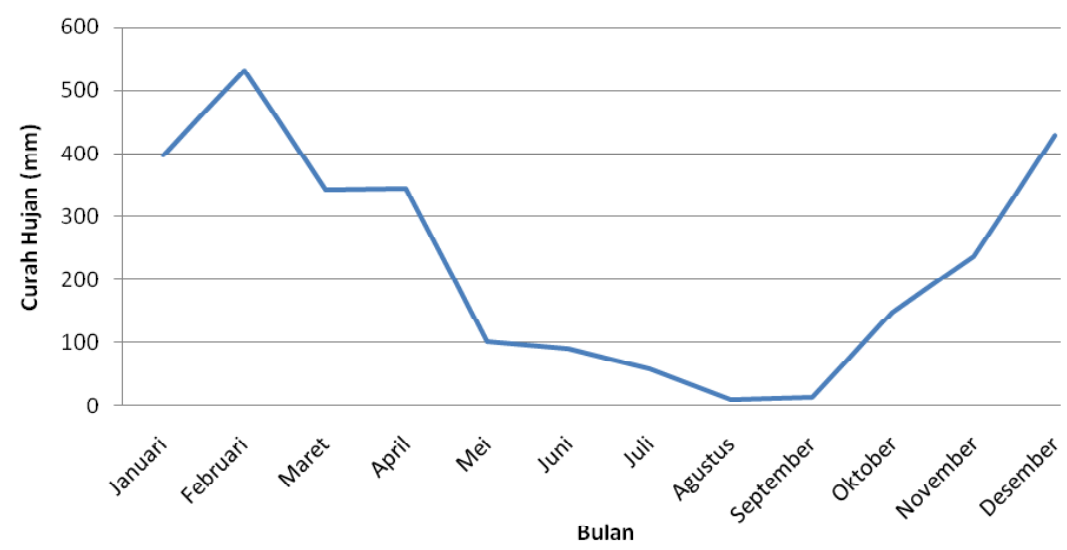

Gambar 1. Grafik Volume Hujan Desa Kepuharjo dalam Satu Tahun

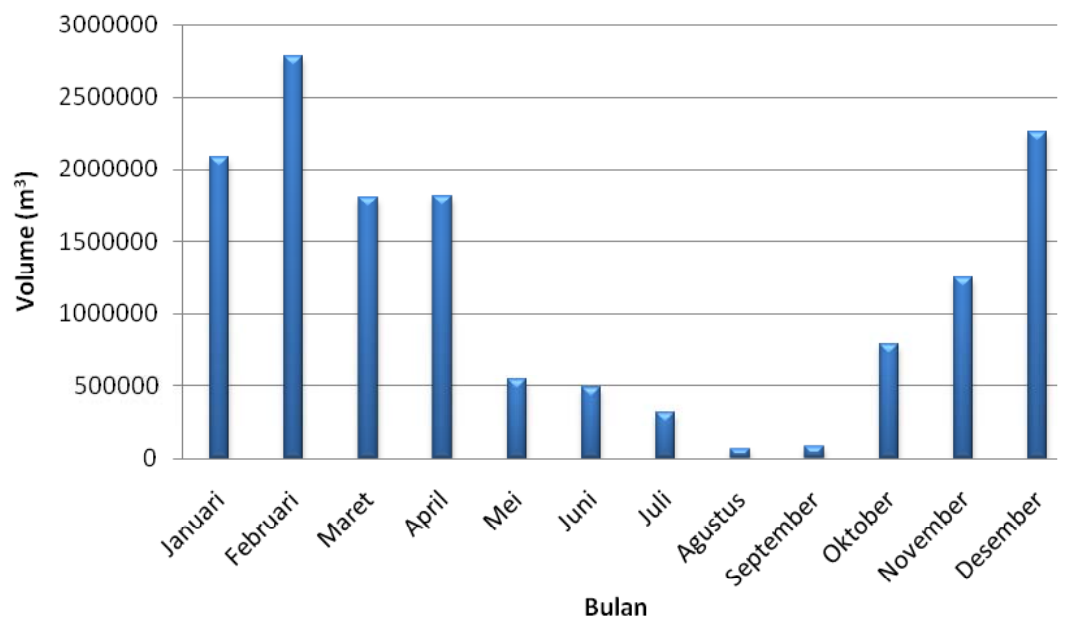

Gambar 2. Grafik Rerata Curah Hujan Desa Kepuharjo

2) Mata Air

Potensi mata air Desa Kepuharjo merupakan aliran air yang bersumber dari mataair Bebeng dan Kali Kuning melalui saluran air Plunyon. Air tersebut dialirkan ke rumah-rumah penduduk melalui pipa dan ditampung di bak-bak penampungan sementara. Dari mataair Bebeng didapatkan aliran yang menuju ke Desa Kepuharjo memiliki debit sebesar 17,53 liter/detik pada musim penghujan sedangkan pada musim kemarau hanya 9 liter/detik. Sementara itu, debit dari mataair Kalikuning sebesar 2,28 liter/detik.

Perhitungan potensi air permukaan total di Desa Kepuharjo didasarkan pada banyaknya air yang masuk ke wilayah Desa Kepuharjo. Analisis dilakukan hanya pada air permukaan dan tidak memperhitungkan volume air tanah yang ada di wilayah Desa Kepuharjo. Air permukaan yang dimaksud adalah air yang 
bersumber dari air hujan dan aliran air dari mataair Bebeng dan Kalikuning melalui saluran Plunyon. Pada musim penghujan, ketersediaan air di Desa Kepuharjo mencapai $1282852.99 \mathrm{~m}^{3}$ sedangkan pada musim kemarau, Desa Kepuharjo hanya memiliki ketersediaan air sebanyak $155006.118 \mathrm{~m}^{3}$. Berikut ini adalah tabel mengenai volume ketersediaan air di Desa Kepuharjo yang berasal bersumber dari mataair dan hujan.

Tabel 3.

Ketersediaan Air Desa Kepuharjo

\begin{tabular}{cccc}
\hline \multirow{2}{*}{ Bulan } & \multicolumn{2}{c}{ Sumber Air } & \multirow{2}{*}{ Ketersediaan Air $\left(\mathbf{m}^{3}\right)$} \\
\cline { 2 - 3 } & Mataair $\left(\mathrm{m}^{3}\right)$ & Hujan $\left(\mathrm{m}^{3}\right)$ & \\
\hline Januari & 51347.52 & 162318.5 & 213666 \\
\hline Februari & 51347.52 & 216968.4 & 268315.9 \\
\hline Maret & 51347.52 & 140295.4 & 191642.9 \\
\hline April & 51347.52 & 141111 & 192458.6 \\
\hline Mei & 51347.52 & 42414.88 & 93762.4 \\
\hline Juni & 29237.76 & 37928.69 & 67166.45 \\
\hline Juli & 29237.76 & 24470.12 & 53707.88 \\
\hline Agustus & 29237.76 & 4894.025 & 34131.78 \\
\hline September & 29237.76 & 6117.531 & 35355.29 \\
\hline Oktober & 51347.52 & 61175.31 & 112522.8 \\
\hline November & 51347.52 & 97064.82 & 148412.3 \\
\hline Desember & 51347.52 & 175369.2 & 226716.7 \\
\hline Jumlah & $\mathbf{5 2 7 7 3 1 . 2}$ & $\mathbf{1 1 1 0 1 2 8}$ & $\mathbf{1 6 3 7 8 5 9}$ \\
\hline
\end{tabular}

Sumber : Hasil Pengolahan Data

\section{Kebutuhan Air Total}

Pemanfaatan air di Desa Kepuharjo meliputi kebutuhan domestik dan non domestik. Kebutuhan domestik meliputi kebutuhan sehari-hari penduduk seperti penggunaan air untuk minum, MCK dan sebagainya. Sedangkan pemanfaatan untuk kebutuhan non domestik meliputi kegiatan peternakan, pendidikan, masjid/musholla, pariwisata, dan instansi pemerintah. Berikut ini adalah tabel yang menunjukkan banyaknya air yang dikonsumsi oleh setiap sektor tersebut.

Tabel 4.

Ketersediaan Air Desa Kepuharjo

\begin{tabular}{clcc}
\hline No. & \multicolumn{1}{c}{ Sektor } & $\mathbf{m}^{3} / \mathbf{b u l a n}$ & Persentase (\%) \\
\hline 1 & Kebutuhan Domestik & 47572.8 & 91.97473 \\
\hline 2 & Peternakan & 3717.633 & 7.187475 \\
\hline 3 & Pendidikan & 278.41 & 0.538263 \\
\hline
\end{tabular}




\begin{tabular}{rlcc}
\hline 4 & Masjid dan musholla & 87.9 & 0.169941 \\
\hline 5 & Pariwisata & 23.35 & 0.045144 \\
\hline 6 & Instansi pemerintahan & 43.68 & 0.084449 \\
\hline & Jumlah & $\mathbf{5 1 7 2 3 . 7 7}$ & $\mathbf{1 0 0}$ \\
\hline
\end{tabular}

Sumber : Hasil Pengolahan Data

Pemanfaatan air untuk kebutuhan domestik di Desa Kepuharjo adalah yang paling mendominasi, mencapai $47572.8 \mathrm{~m} 3 /$ bulan atau dengan kata lain pemanfaatan airnya sekitar $91.97 \%$ dari pemanfaatan air totalnya yang mencapai $51723.77 \mathrm{~m} 3 /$ bulan.

\section{Kekritisan Air}

Suatu wilayah dikatakan kritis air apabila kebutuhan air masyarakat tidak dapat sebanding dengan potensi ketersediaan air yang ada di wilayah tersebut. Desa Kepuharjo, berdasarkan pada hasil analisis yang dilakukan mengalamai kekritisan air terutama pada musim kemarau sedangkan pada musim penghujan mengalami surplus air yang sangat banyak. Berikut ini adalah tabel yang menyajikan perbandingan antara ketersediaan dan kebutuhan air di Desa Kepuharjo secara umum.

Tabel 5.

Kelas Kekritisan Air Desa Kepuharjo

\begin{tabular}{ccccc}
\hline Bulan & $\begin{array}{c}\text { Ketersediaan Air } \\
\left(\mathbf{m}^{3}\right)\end{array}$ & $\begin{array}{c}\text { Kebutuhan Air } \\
\left(\mathbf{m}^{3}\right)\end{array}$ & $\begin{array}{c}\text { Indeks } \\
\text { Kekritisan }\end{array}$ & Kelas Kekritisan \\
\hline Januari & 213666 & 51723.77 & 24.20777 & Belum Kritis \\
\hline Februari & 268315.9 & 51723.77 & 19.27719 & Belum Kritis \\
\hline Maret & 191642.9 & 51723.77 & 26.98966 & Belum Kritis \\
\hline April & 192458.6 & 51723.77 & 26.87528 & Belum Kritis \\
\hline Mei & 93762.4 & 51723.77 & 55.16473 & Mendekati Kritis \\
\hline Juni & 67166.45 & 51723.77 & 77.00835 & Kritis \\
\hline Juli & 53707.88 & 51723.77 & 96.30574 & Kritis \\
\hline Agustus & 34131.78 & 51723.77 & 151.5414 & Sangat Kritis \\
\hline September & 35355.29 & 51723.77 & 146.2971 & Sangat Kritis \\
\hline Oktober & 112522.8 & 51723.77 & 45.96736 & Belum Kritis \\
\hline November & 148412.3 & 51723.77 & 34.8514 & Belum Kritis \\
\hline Desember & 226716.7 & 51723.77 & 22.81427 & Belum Kritis \\
\hline Jumlah & $\mathbf{1 6 3 7 8 5 9}$ & $\mathbf{5 1 7 2 3 . 7 7}$ & $\mathbf{3 . 1 5 8 0 1 1}$ & Belum Kritis \\
\hline Sur & & & &
\end{tabular}

Sumber: Hasil Pengolahan Data 
Secara umum, pada satu tahun, Desa Kepuharjo belum mengalami kekritisan air secara signifikan. Hanya saja, pada musim kemarau, desa ini terancam mengalami kekritisan akhir. Indeks kekritisan paling tinggi adalah pada bulan Agustus hingga September. Pada kedua bulan tersebut terjadi kekritisan air yang sangat parah. Kebutuhan penduduk akan air tidak dapat diimbangi oleh ketersediaan air yang ada baik dari sumber mataair maupun air hujan. Berdasarkan pada hasil survai, didapati bahwa pada bulan-bulan kering, banyak penduduk yang membeli air dari luar desa keterbatasan pasokan air di desa ini.

Analisis mengenai kekritisan air ini dapat didetilkan lagi hingga pada level dusun. Setiap dusun di Desa Kepuharjo memiliki perbedaan dalam hal volume penggunaan airnya. Berikut ini adalah perbandingan kebutuhan air di setiap dusun di Desa Kepuharjo yang menentukan tingkat kekritisan airnya.
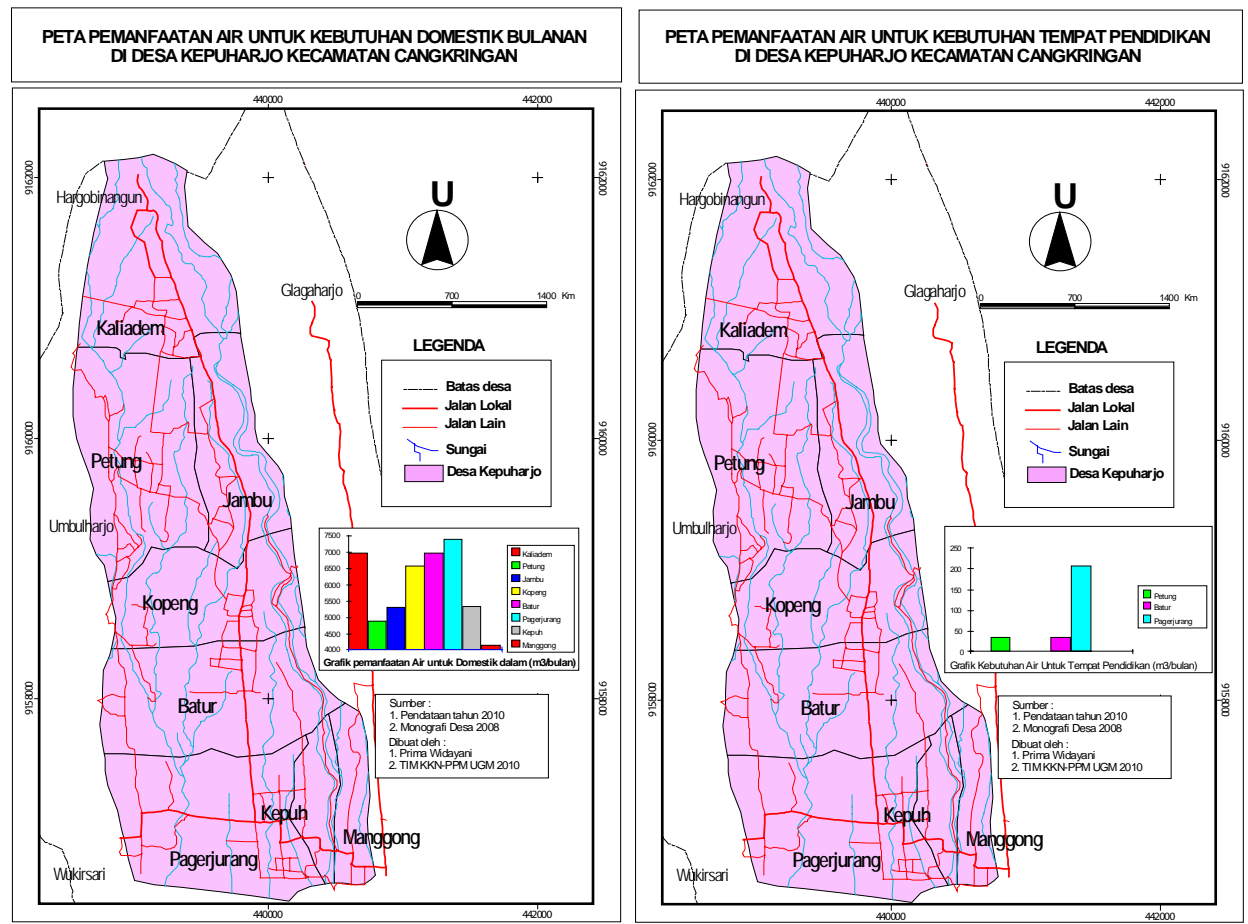

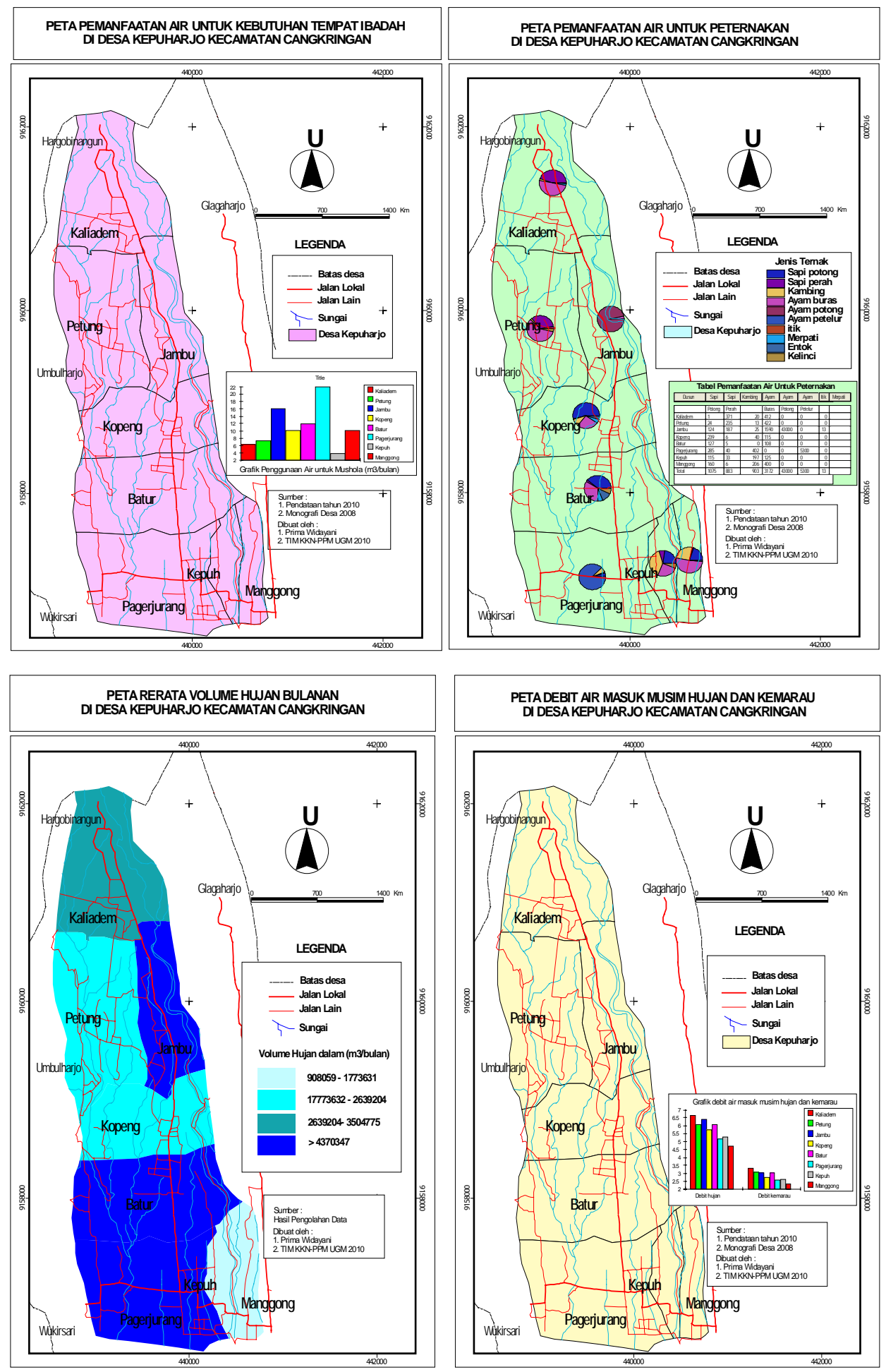

Prima Widayani, Penyusunan Basis Data Spasial Sumberdaya Air 


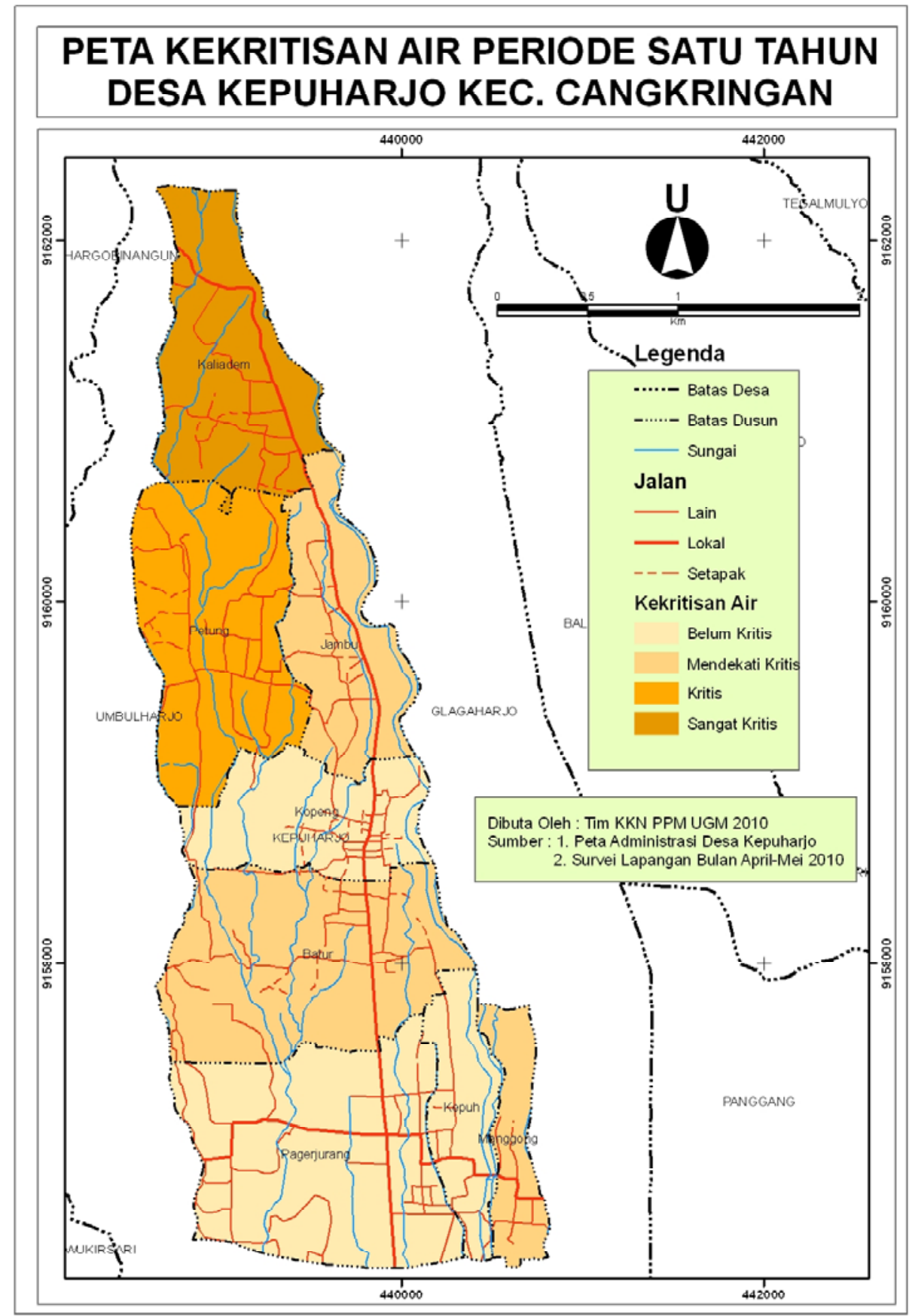




\section{SIMPULAN}

Simpulan penelitian adalah: 1) air hujan dan aliran air yang dialirkan melalui pipa dari mataair Bebeng dan Kalikuning menjadi sumber air permukaan utama penduduk Desa Kepuharjo; 2) Desa Kepuharjo memiliki potensi air permukaan yang sangat tinggi terutama pada musim penghujan dan belum dimanfaatkan secara optimal; 3) tingkat kekritisan air di Desa Kepuharjo sangat relatif tinggi terutama pada bulan Agustus dan September; dan 4) kajian mengenai pengelolaan sumber daya air menjadi sangat penting untuk meminimalisasi kemungkinan kelangkaan air.

\section{DAFTAR PUSTAKA}

Ato Suprapto, Ato. (2010). Land and Water Resources Development in Indonesia. Director General Agriculture Infrastructure Ministry of Agriculture, Indonesia

Anonim . (2008). RPJM Desa Kepuharjo Tahun 2008. Kepuharjo.

Bappeda. (2009). Laporan Akhir Kajian Potensi Sumberdaya Air Sleman Timur. Sleman : Badan Perencanaan Pembangunan Daerah Kabupaten Sleman.

Bina Program Pengairan. (2005). Klasifikasi Tingkat Kekritisan Air. Sleman: Bina Program Pengairan.

IFAD. (2009). Good Practices in Participatory Mapping. International Found for Agricultural Development.

Plan. (2010). Community Development.Plan International Indonesia.

Stefano Di Gessa. (2008). Participatory Mapping as a Tool for Empowerment. International Land Coalition. 